
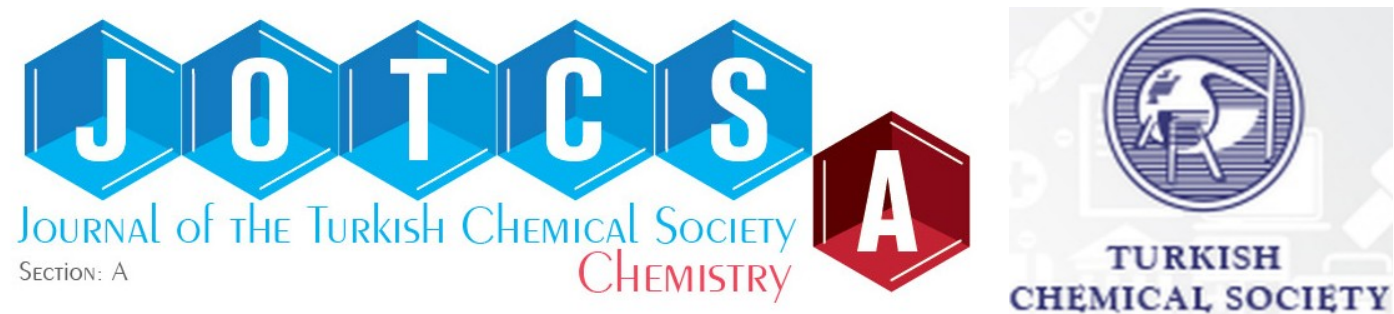

\title{
Dyeing Polyester, Cotton and Wool with Some Schiff Bases Derived from 4-chloroaminophenol and Various Benzaldehydes
}

\author{
Demet GüRBÜZ* $*$ iD
}

${ }^{1}$ University of Istanbul-Cerrahpasa, Faculty of Engineering, Department of Chemistry, 34320, Istanbul, Turkey.

Abstract: Dyeability of ten Schiff bases obtained from 4-chloroaminophenol and various benzaldehydes including methyl, chloro, bromo, nitro, methoxy, and hydroxy groups were investigated on polyester, cotton and wool fibers. The dry/wet rubbing and washing fastness of the compounds were measured. It is observed that the rubbing and washing fastness values are varying at the $4-5$ range (1: weak, 5: excellent). The lightness (L), red-greenness (a), and yellow-blueness (b) properties of the compounds were also investigated. It was observed that the dyeing properties of the compounds change depending on the substituent positions, and the substituent effect is observed on wool mostly. Especially, 3- and 5-methyl derivatives (VIII and IX) exhibit similar behavior toward polyester and cotton while they behave differently on wool in point of the $\mathbf{L}, \mathbf{a}$, and $\mathbf{b}$ values. On the other hand, it can be claimed that chlorine substituent increases the $\mathbf{L}$ value on wool.

Keywords: Schiff bases, dyeability, polyester, cotton, wool.

Submitted: April 04, 2020. Accepted: May 04, 2020. (This will be filled in by the journal staff).

Cite this: Gürbüz D. Dyeing Polyester, Cotton and Wool with Some Schiff Bases Derived from 4chloroaminophenol and Various Benzaldehydes. JOTCSA. 2020; 7(2): 463-70.

DOI: https://doi.org/10.18596/jotcsa.714635.

*Corresponding author. E-mail: demet@istanbul.edu.tr.

\section{INTRODUCTION}

Schiff bases have considerable interest due to a large number of biological activities, including anticancer (1-3), antibacterial (4-6), antiviral (7-9), antifungal (10-12), antimalarial (13), urease inhibition (14-15), antioxidant agents (16-17) and DNA binding ability (18-19). The presence of $\mathrm{C}=\mathrm{N}$ functional group in Schiff bases is responsible for the biological activities (20). Intramolecular hydrogen bonding between the phenolic group and the azomethine nitrogen atoms of Schiff bases derived from aromatic o-hydroxy aldehydes impacts the properties of various molecular systems and plays an essential role in many biochemical reactions (21).

Besides, the synthesis of Schiff bases has been increasing attention in synthetic organic chemistry, because of their potential applications in biological modeling, catalysis, design of molecular magnets and materials chemistry (22-24) and also widely used as chelating agents (25-27), as corrosion inhibitors (28-29), as an herbicide (30), as textile dyes (31), as stabilizers in polymer chemistry (32).

Polyester is a synthetic fiber which is the most widely used in the textile industry due to their advantageous properties, including high tenacity, good resistance to chemicals, and deformation. Polyester fiber is preferred because of its hydrophobic nature and has a highly compact structure that permits efficient dyeing at high temperatures with disperse dyes.

The present study reports the investigation of the dyeability of some Schiff bases synthesized from 4chloroaminophenol and various benzaldehydes. Polyester, cotton, and wool fabrics dyeing with conventional aqueous dyeing (batch dyeing) methods are studied in this context. 


\section{EXPERIMENTAL SECTION}

\section{General}

All reagents were commercially available and used as received without further purification. Elemental analysis data were recorded on a Thermo Finnigan Flash EA 1112 analyzer. The FTIR spectra were obtained with a Bruker Optics Vertex 70 spectrometer (ATR). UV-Visible spectra were measured using a Perkin Elmer Lambda 25 UV/Visible Spectrophotometer. The Electron Spray Ionization-Mass Spectroscopy (ESI-MS) analyses were recorded on a Thermo Finnigan LCQ Advantage MAX LC/MS/MS. Dyeing was performed

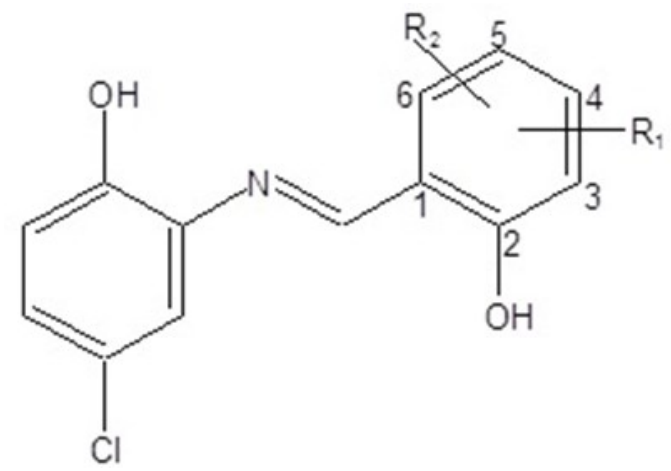

at a TERMAL Dyeing Lab. Machine. The used polyester $\left(110 \mathrm{~g} / \mathrm{m}^{2}\right)$, wool $\left(120 \mathrm{~g} / \mathrm{m}^{2}\right)$, and cotton $\left(110 \mathrm{~g} / \mathrm{m}^{2}\right)$ fabrics for dyeing procedure are $100 \%$ woven. Decacid Sab was used as a dispersing agent.

\section{General Procedure for the Preparation of Schiff Bases}

The Schiff bases were synthesized by condensation of 4-chloro-2-aminophenol (1.44 g; $10 \mathrm{mmol})$ with an appropriate aldehyde (e.g., 2,4dihydroxybenzaldehyde for $\mathbf{V}, 1.38 \mathrm{~g} ; 10 \mathrm{mmol}$ ) in $20 \mathrm{~mL}$ of EtOH. This mixture was stirring under reflux for $3 \mathrm{~h}$. After the heading, the mixture was allowed to cool to room temperature. The solid product was separated by filtration and then crystallized from $\mathrm{CH}_{3} \mathrm{OH}$ (33-34).

Scheme 1. The chemical structures of Schiff bases $\mathbf{I}-\mathbf{X}$ used in this study.

I: Yellow-orange solid. Yield: 90\%, m.p.: $201{ }^{\circ} \mathrm{C}$. Elemental analysis: Calculated for $\mathrm{C}_{13} \mathrm{H}_{9} \mathrm{BrClNO}_{2}: \mathrm{C}$, 47.82; H, 3.28; N, 4.56; Found: $\mathrm{C}, 47.81 ; \mathrm{H}, 2.78$; $\mathrm{N}, 4.29$. FT-IR (ATR, v/cm $\left.{ }^{-1}\right): 3071 \mathrm{~m}, \mathrm{br}, 2925$ m,br, 2854 m,br, 2587 m, 1628 m, 1607 w, 1504 s, $1288 \mathrm{~m}, 1231 \mathrm{~m}, 1177 \mathrm{~m}, 1123 \mathrm{~m}, 816 \mathrm{~m}, 656 \mathrm{~m}$, $525 \mathrm{w}$. UV $\left(10^{-4} \mathrm{M}\right.$, in methanol): $456 \mathrm{sh}, 364 \mathrm{~m}, \mathrm{br}$, 262 m, 214 s. MS (ESI), m/z (\%) (MA: 326.57 $\mathrm{g} / \mathrm{mol}): 324.6\left(38.0,[\mathrm{M}-2]^{+}\right), 325.4,326.7,327.5$, $328.6,329.7$.

II: Orange solid. Yield: 96\%, m.p.: $203{ }^{\circ} \mathrm{C}$. Elemental analysis: Calculated for $\mathrm{C}_{13} \mathrm{H}_{9} \mathrm{Cl}_{2} \mathrm{NO}_{2}$ : C 54.17; $\mathrm{H}, 3.41 ; \mathrm{N}, 5.08$; Found : $\mathrm{C}, 55.34 ; \mathrm{H}, 3.22$; $\mathrm{N}$, 4.96. FT-IR (ATR, v/cm ${ }^{-1}$ ): $3072 \mathrm{~m}, \mathrm{br}, 2926$ $\mathrm{m}, \mathrm{br}, 2542 \mathrm{~m}, \mathrm{br}, 1628 \mathrm{~s}, 1452 \mathrm{~m}, 1208 \mathrm{~m}, 1154$ m, $1093 \mathrm{~m}, 1018 \mathrm{~m}, 910 \mathrm{~m}, 831 \mathrm{~s}, 698 \mathrm{w}$. UV $\left(10^{-4}\right.$ $M$, in methanol): $452 \mathrm{w}, \mathrm{br}, 364 \mathrm{~m}, \mathrm{br}, 269 \mathrm{~m}, 234$ sh, 215 s. MS (ESI), m/z (\%) (MA: $282.12 \mathrm{~g} / \mathrm{mol})$ : $280.6\left(100,[\mathrm{M}-2]^{+}\right), 281.7\left(11.7,[\mathrm{M}-1]^{+}\right), 282.5$ $\left(65.6,[\mathrm{M}]^{+}\right), 283.6\left(8.1,[\mathrm{M}+1]^{+}\right), 284.5(9.6$, $\left.[\mathrm{M}+2]^{+}\right)$.

III: Orange solid. Yield: 93\%, m.p.: $271{ }^{\circ} \mathrm{C}$. Elemental analysis: Calculated for $\mathrm{C}_{13} \mathrm{H}_{8} \mathrm{BrCl}_{2} \mathrm{NO}_{2}$ : C, 43.40; H, 2.19; N, 3.70; Found : C, 43.25; H, 2.32; $\mathrm{N}$, 3.88. FT-IR (ATR, v/cm $\left.{ }^{-1}\right): 3214 \mathrm{~m}, \mathrm{br}, 3059$ m,br, 2925 m,br, 1628 s, 1499 s, 1438 m, 1305 m,

$\begin{array}{cll}\text { Compound } & \mathbf{R}_{\mathbf{1}} & \mathbf{R}_{\mathbf{2}} \\ \mathbf{I} & \mathrm{H} & 5-\mathrm{Br} \\ \text { II } & \mathrm{H} & 5-\mathrm{Cl} \\ \text { III } & 3-\mathrm{Br} & 5-\mathrm{Cl} \\ \text { IV } & 3-\mathrm{Cl} & 5-\mathrm{Cl} \\ \mathbf{V} & 4-\mathrm{OH} & \mathrm{H} \\ \text { VI } & 3-\mathrm{OCH}_{3} & \mathrm{H} \\ \text { VII } & 4-\mathrm{OCH}_{3} & \mathrm{H} \\ \text { VIII } & 3-\mathrm{CH}_{3} & \mathrm{H} \\ \text { IX } & \mathrm{H} & 5-\mathrm{CH}_{3} \\ \mathbf{X} & \mathrm{H} & 5-\mathrm{NO}_{2}\end{array}$

1226 s, 1145 m, $1021 \mathrm{~m}, 915 \mathrm{~m}, 845 \mathrm{~m}, 739 \mathrm{~m}$, $664 \mathrm{~m}$. UV $\left(10^{-4} \mathrm{M}\right.$, in methanol): $462 \mathrm{w}, \mathrm{br}, 440 \mathrm{sh}$, 367 m,br, 269 m, 211 s. MS (ESI), m/z (\%) (MA: $361.02 \mathrm{~g} / \mathrm{mol}): 358.8\left(41.4,[\mathrm{M}-2]^{+}\right), 359.9(6.0$, $\left.[\mathrm{M}-1]^{+}\right), 360.8\left(100,[\mathrm{M}]^{+}\right), 361.7\left(15.9,[\mathrm{M}+1]^{+}\right)$, $362.5\left(49.7,[M+1]^{+}\right), 363.2\left(43.0,[M+2]^{+}\right), 364.1$ $\left(9.8 ;[\mathrm{M}+3]^{+}\right), 364.8\left(11.7,[\mathrm{M}+4]^{+}\right), 365.7(5.0$, $\left.[\mathrm{M}+5]^{+}\right)$.

IV: Orange solid. Yield: 95\%, m.p.: $279{ }^{\circ} \mathrm{C}$. Elemental analysis: Calculated for $\mathrm{C}_{13} \mathrm{H}_{8} \mathrm{Cl}_{3} \mathrm{NO}_{2}$ : C, 49.18; H, 2.74; N, 4.56; Found: $\mathrm{C}, 49.32 ; \mathrm{H}, 2.55$; $\mathrm{N}$, 4.42. FT-IR (ATR, v/cm $\left.{ }^{-1}\right): 3164 \mathrm{~m}, \mathrm{br}, 3063$ $\mathrm{m}, \mathrm{br}, 2921 \mathrm{~m}, 1628 \mathrm{~s}, 1508 \mathrm{~s}, 1438 \mathrm{~m}, 1217 \mathrm{~s}$, $1149 \mathrm{~m}, 1034 \mathrm{~m}, 854 \mathrm{~m}, 761 \mathrm{~m}, 660 \mathrm{w}$. UV $\left(10^{-4}\right.$ $\mathrm{M}$, in methanol): $463 \mathrm{~m}, \mathrm{br}, 437 \mathrm{sh}, 365 \mathrm{~m}, \mathrm{br}, 269$ $\mathrm{m}, 213 \mathrm{~s}$. MS (ESI), m/z (\%) (MA: $316.57 \mathrm{~g} / \mathrm{mol})$ : $314.7(87.2, \mathrm{M}-2), 316.6\left(100, \mathrm{CM}^{+}\right), 317.7$ (14.6, $\left.[M+1]^{+}\right), 318.6\left(31.5,[M+2]^{+}\right), 319.5(5.4, M+3)$, $320.5(4.4, M+4)$.

V: Dark yellow solid. Yield: 73\%, m.p.: $221{ }^{\circ} \mathrm{C}$. Elemental analysis: Calculated for $\mathrm{C}_{13} \mathrm{H}_{10} \mathrm{CINO}_{2}$ : C, 58.89; H, 3.84; N, 5.50; Found : C, 59.22; H, 3.82; $\mathrm{N}$, 5.31. FT-IR $\left(A T R, \mathrm{v} / \mathrm{cm}^{-1}\right): 3178 \mathrm{~m}, \mathrm{br} \bullet(\mathrm{OH})$, 3072 m,br, 2926 m, 2553 m,br, 1637 s, 1592 m, 1269 s, 1228 s, 1131 m, 989 m, 915 m, 849 m, 790 $\mathrm{m}, 662 \mathrm{w}$. UV $\left(10^{-4} \mathrm{M}\right.$, in methanol): $422 \mathrm{~m}, \mathrm{br}, 352$ 
m,br, 269 m, 228 sh, 212 s. MS (ESI), m/z (\%) (MA: $263.67 \mathrm{~g} / \mathrm{mol}): 264.5\left(38.0,[\mathrm{M}+1]^{+}\right), 265.8$ $\left(17.2,[\mathrm{M}+2]^{+}\right), 509.3(100,[2 \mathrm{M}-\mathrm{OH}]), \quad 511.3$ (71.9), 525.5 (56.7), 526.5 (20.8), 527.5 (22.0).

VI: Bright yellow solid. Yield: 85\%, m.p.: $219{ }^{\circ} \mathrm{C}$. Elemental analysis: Calculated for $\mathrm{C}_{14} \mathrm{H}_{12} \mathrm{CINO}_{3}$ : C, 60.82; H, 4.46; N, 5.01; Found : C, 60.55; H, 4.36; $\mathrm{N}$, 5.04. FT-IR (ATR, v/cm $\left.{ }^{-1}\right): 3071 \mathrm{~m}, \mathrm{br}, 2970$ m,br, 2909 m,br, 1649 s, 1621 s, 1592 m, 1525 m, 1504 s, 1479 s, 1429 s, 1278 m, 1226 s, 903 m, $831 \mathrm{~m}, 800 \mathrm{~m}, 772 \mathrm{~m}, 656 \mathrm{~m}$. UV $\left(10^{-4} \mathrm{M}\right.$, in methanol): $446 \mathrm{sh}, 426 \mathrm{~m}, \mathrm{br}, 351 \mathrm{~s}, \mathrm{br}, 304 \mathrm{~m}, \mathrm{br}$, 285 sh, 242 s,br, 215 sh. MS (ESI), m/z (\%) (MA: $277.50 \mathrm{~g} / \mathrm{mol}): 276.67\left(77.6,[\mathrm{M}-1]^{+}\right), 278.69$ $\left(100,[M+1]^{+}\right), 280.16\left(30.4,[M+3]^{+}\right)$.

VII: Red solid. Yield: $50 \%$, m.p.: $145^{\circ} \mathrm{C}$. Elemental analysis: Calculated for $\mathrm{C}_{14} \mathrm{H}_{12} \mathrm{CINO}_{3}$ : C, 60.75; $\mathrm{H}$, 4.48; N, 5.00; Found : C, 60.55; H, 4.36; N, 5.04. FT-IR (ATR, v/cm ${ }^{-1}$ ): $3054 \mathrm{~m}, \mathrm{br}, 3002 \mathrm{~m}, \mathrm{br}, 2930$ $\mathrm{m}, \mathrm{br}, 1623 \mathrm{~s}, 1594 \mathrm{~m}, 1504 \mathrm{~s}, 1443 \mathrm{~m}, 1251 \mathrm{~m}$, $1140 \mathrm{~m}, 906 \mathrm{~m}, 827 \mathrm{~m}, 799 \mathrm{~m}, 646 \mathrm{~m}$. UV $\left(10^{-4} \mathrm{M}\right.$, in methanol): $482 \mathrm{w}, \mathrm{br}, 373 \mathrm{~m}, \mathrm{br}, 354 \mathrm{sh}, 273 \mathrm{~s}$, 252 sh, 236 s,br, 219 sh. MS (ESI), m/z (\%) (MA: $277.50 \mathrm{~g} / \mathrm{mol}): 276.72\left(100,[\mathrm{M}-1]^{+}\right), 278.71$ $\left(71.3,[\mathrm{M}+1]^{+}\right), 280.37\left(24.4,[\mathrm{M}+3]^{+}\right)$.

VIII: Light orange solid. Yield: $97 \%$, m.p.: $220^{\circ} \mathrm{C}$. Elemental analysis: Calculated for $\mathrm{C}_{14} \mathrm{H}_{12} \mathrm{ClNO}_{2}$ : C, 64.20; H, 4.83; N, 5.42; Found: C, 64.25; H, 4.62; $\mathrm{N}$, 5.35. FT-IR $\left(A T R, v / \mathrm{cm}^{-1}\right): 3071 \mathrm{~m}, \mathrm{br}, 2920 \mathrm{~m}$, $2673 \mathrm{~m}, \mathrm{br}, 2562 \mathrm{~m}, \mathrm{br}, 1624 \mathrm{~s}, 1595 \mathrm{sh}, 1441 \mathrm{~m}$, 1232 s, $1162 \mathrm{~m}, 1036 \mathrm{~m}, 817 \mathrm{~m}, 762 \mathrm{~m}, 662 \mathrm{w}$. UV ( $\mathrm{nm}, 10^{-4} \mathrm{M}$, in methanol): $452 \mathrm{w}, \mathrm{br}, 352 \mathrm{~m}, \mathrm{br}, 269$ $\mathrm{m}, \mathrm{br}, 215$ s. MS (ESI), m/z (\%) (MA: 261.70 $\mathrm{g} / \mathrm{mol}): 262.6\left(100,[\mathrm{M}+1]^{+}\right), 263.5\left(30.7,[\mathrm{M}+2]^{+}\right)$.

IX: Orange solid. Yield: 85\%, m.p.: $173{ }^{\circ} \mathrm{C}$. Elemental analysis: Calculated for $\mathrm{C}_{14} \mathrm{H}_{12} \mathrm{CINO}_{2}$ : C, 64.34; $\mathrm{H}, 4.51$; N, 5.11; Found: $\mathrm{C}, 64.25 ; \mathrm{H}, 4.62$; $\mathrm{N}$, 5.35. FT-IR (ATR, v/cm ${ }^{-1}$ ): $3428 \mathrm{~m}, 2925 \mathrm{~m}$, 1631 s, 1585 m, 1508 s, 1438 m, 1294 m, 1240 m, $1162 \mathrm{~m}, 922 \mathrm{~m}, 822 \mathrm{~m}, 656 \mathrm{w}$. UV $\left(\mathrm{nm}, 10^{-4} \mathrm{M}\right.$, in methanol): $451 \mathrm{w}, \mathrm{br}, 359 \mathrm{~m}, \mathrm{br}, 269 \mathrm{~m}, 237 \mathrm{sh}, 214$ s. $M S(E S I), m / z(\%)(M A: 261.70 \mathrm{~g} / \mathrm{mol}): 262.5$ $\left(31.6,[\mathrm{M}+1]^{+}\right), 261.6\left(10.5,[\mathrm{M}]^{+}\right), 260.6(100,[\mathrm{M}-$ $\left.1]^{+}\right)$.

X: Yellowish orange solid. Yield: 74\%, m.p.: 268 ${ }^{\circ} \mathrm{C}$. Elemental analysis: Calculated for $\mathrm{C}_{13} \mathrm{H}_{9} \mathrm{ClN}_{2} \mathrm{O}_{4}$ : C, 53.44; $\mathrm{H}, 3.26 ; \mathrm{N}, 9.74$; Found : C, 53.35; $\mathrm{H}$, 3.10; N, 9.57. FT-IR (ATR, v/cm $\left.{ }^{-1}\right): 3066 \mathrm{~m}, 2925$ m,br, 2774 m,br, 2557 m,br, 1649 s, 1623 s, 1446 m, $1391 \mathrm{~m}, 1296 \mathrm{~s}, 1238 \mathrm{~m}, 1192 \mathrm{~m}, 1151 \mathrm{~m}$, $1100 \mathrm{~m}, 1038 \mathrm{~m}, 901 \mathrm{~m}, 837 \mathrm{~m}, 755 \mathrm{~m}, 639 \mathrm{~m}$. UV ( $\mathrm{nm}, 10^{-4} \mathrm{M}$, in methanol): $461 \mathrm{sh}, 426 \mathrm{~m}, \mathrm{br}, 350$ $\mathrm{m}, \mathrm{br}, 269 \mathrm{~m}, 262 \mathrm{~m}, 211 \mathrm{~s}$. MS (ESI), m/z (\%) (MA: $292.67 \mathrm{~g} / \mathrm{mol}): 290.3\left(100,[\mathrm{M}-2]^{+}\right), 292.4$ $\left(65.7,[\mathrm{M}]^{+}\right), 293.5\left(29.3,[\mathrm{M}+1]^{+}\right) 294.5(28.6$, $\left.[\mathrm{M}+2]^{+}\right)$.

\section{Dyeing Polyester Fabrics}

The polyester samples were dyed with an HT sample dyeing machine. Dyebath was prepared with dye, which was synthesized, nonionic dispersant $(0.5$ $\mathrm{g} / \mathrm{L}$ ), and $\mathrm{CH}_{3} \mathrm{COOH}(\mathrm{pH} \sim 5)$ with a liquor ratio of $1: 20$. The temperature was raised to $130{ }^{\circ} \mathrm{C}$ at a rate of $3{ }^{\circ} \mathrm{C} / \mathrm{min}$. Within $30 \mathrm{~min}$. and the dyeing continued for $60 \mathrm{~min}$. After completion of dyeing, reduction cleaning of the samples were rinsed with warm water and were subjected to neutralization with a solution containing $\mathrm{Na}_{2} \mathrm{~S}_{2} \mathrm{O}_{4}$ and $\mathrm{NaOH}(2 \mathrm{~g} / \mathrm{L}$ each) at $70{ }^{\circ} \mathrm{C}$ for $10 \mathrm{~min}$. To remove the superficial dye, the polyester was rinsed with cold water at 50 ${ }^{\circ} \mathrm{C}$ for $10 \mathrm{~min}$. and washed with water and air-dried.

\section{Dyeing Cotton Fabrics}

The cotton samples were dyed with an HT sample dyeing machine. Dyebath was prepared with dye, which was synthesized, nonionic dispersant (0.5 $\mathrm{g} / \mathrm{L})$, and $\mathrm{Na}_{2} \mathrm{CO}_{3}(\mathrm{pH} \sim 10)$ with a liquor ratio of $1: 20$. The temperature was raised to $90^{\circ} \mathrm{C}$ at a rate of $6^{\circ} \mathrm{C} / \mathrm{min}$ within $30 \mathrm{~min}$, and the dyeing continued for $90 \mathrm{~min}$. After completion of dyeing, the samples were rinsed two times for $10 \mathrm{~min}$. with water at 60 ${ }^{\circ} \mathrm{C}$ and air-dried.

\section{Dyeing Wool Fabrics}

The wool samples were dyed with an HT sample dyeing machine. Dyebath was prepared with dye, which was synthesized, nonionic dispersant $(0.5$ $\mathrm{g} / \mathrm{L}$ ), and $\mathrm{CH}_{3} \mathrm{COOH}(\mathrm{pH} \sim 5)$ with a liquor ratio of $1: 20$. The temperature was raised to $80^{\circ} \mathrm{C}$ at a rate of $8{ }^{\circ} \mathrm{C} / \mathrm{min}$ and then held at this temperature for $90 \mathrm{~min}$. and the dyeing continued for $60 \mathrm{~min}$. After completion of dyeing, the samples were removed, thoroughly rinsed with water for $10 \mathrm{~min}$. at $40{ }^{\circ} \mathrm{C}$ and air-dried.

\section{Color Fastness Tests}

The reduction cleaning of the dyed samples was measured using the ISO 105 C06 standard method, and ECE was used as washing detergent for this test. The Greyscale was used for evaluating the change in shade and staining of adjacent multifiber test fabrics. Color fastness to rubbing test was evaluated according to the ISO105-X122002 standard method. The color of the dyed fabrics was measured using ISO7724/1 standard method

\section{RESULTS AND DISCUSSIONS}

The Schiff bases used in this study were reported previously (33- 34). The physicochemical and spectroscopic data of the Schiff bases are given at Experimental Section.

Tables 1, 3, and 5 show the washing and rubbing fastness test results of dyes on polyester, cotton, and wool fabrics. Washing and rubbing fastness values of the compounds for polyester, cotton, and wool are detected as 4 or 5 , which considered that these values are specified at the $1-5$ range (1: 
weak, 4: good, 5: excellent). It can be said that the compounds give good fastness properties for washing and rubbing levels as well.

The lightness (L), red-greenness (a), and yellowblueness (b) properties of the compounds, containing different substituents on polyester, wool, and cotton fibers are shown in Tables 2, 4, and 6.

The following points are found by examining the lightness (L), red-greenness (a) and yellowblueness (b) values of the compounds for polyester fabric (Table 2): The $\mathbf{L}$ value of the compound $\mathbf{V I}$ (3-methoxy derivative) is highest, that of III (3$\mathrm{Br}, 5-\mathrm{Cl}$ derivative) is lowest although all $\mathbf{L}$ values are close to each other (between 68.11 and 53.61). Similarly, all the $\mathbf{a}$ and $\mathbf{b}$ values are close to each other, also. The highest $\mathbf{a}$ and $\mathbf{b}$ values are belonging to 3-Me (VIII) and 5- $\mathrm{Br}$ (I) derivatives, 14.52 and 43.34; the lowest ones are 10.27 (VII: 4-methoxy) and 30.01 (III: $3-\mathrm{Br}, 5-\mathrm{Cl}$ ), respectively.

It is seen that the $\mathbf{L}$ and $\mathbf{b}$ values of $5-\mathrm{Br}$ derivative (I) are higher than those of $5-\mathrm{Cl}$ derivative (II), whereas the a value is lower (Table 2). The bromo substituent at the ortho position (III: $3-\mathrm{Br}, 5-\mathrm{Cl}$ ) decreases the $\mathbf{L}, \mathbf{a}$, and $\mathbf{b}$ values comparing to the chloro derivative (IV: $3-\mathrm{Cl}, 5-\mathrm{Cl}$ ) on polyester fabric. It is observed that the $\mathbf{L}$ value of the $5-\mathrm{Br}$ derivative (I) is highest among the compounds having chloro and bromo substituents, namely I, II, III, and IV.

The $\mathbf{L}$ and $\mathbf{a}$ values of the 4-methoxy derivative (meta position, VII) are lower (66.73 and 10.27, respectively) than those of 3-methoxy derivative (VI; L: 68.11, a: 13.41) whereas the $\mathbf{b}$ value is higher (42.43) than that of VI (36.39) towards to polyester fabric (Table 2 ). The $\mathbf{L}$ value of the $3-\mathrm{Me}$ derivative (VIII: methyl group at ortho position) is lower than that of 5-Me derivative (IX: methyl group at the para position) whereas the values of $\mathbf{a}$ and $\mathbf{b}$ are higher than that of 3-Me derivative.

It is seen that the highest $\mathbf{L}$ value is belonging to 5 $\mathrm{Br}$ derivative (I) for cotton fabrics (Table 4), whereas the nitro derivative ( $\mathbf{X})$ shows the lowest $\mathbf{L}$ value. The highest $\mathbf{a}$ and $\mathbf{b}$ values are shown by the compound VIII (3-Me derivative); the lowest a and b values are exhibited by $\mathbf{I}$ and II (5- $\mathrm{Br}$ and $5-\mathrm{Cl}$ derivatives), respectively.

Table 1. Color fastness of the compounds on polyester fabric. ${ }^{(1)}$

\begin{tabular}{|c|c|c|c|c|c|c|c|c|c|}
\hline \multirow{3}{*}{ Compound } & \multicolumn{7}{|c|}{ Washing fastness } & \multicolumn{2}{|c|}{$\begin{array}{l}\text { Rubbing } \\
\text { fastness }\end{array}$} \\
\hline & \multirow{2}{*}{$\begin{array}{c}\text { Color } \\
\text { Change }\end{array}$} & \multicolumn{6}{|c|}{ Staining $^{(2)}$} & \multirow[t]{2}{*}{ Dry } & \multirow[t]{2}{*}{ Wet } \\
\hline & & $\mathrm{AC}$ & $\mathrm{CO}$ & PA & PES & PAN & WO & & \\
\hline I & $4-5$ & $4-5$ & 4 & $4-5$ & $4-5$ & $4-5$ & $4-5$ & $4-5$ & 4 \\
\hline II & 4 & $4-5$ & 4 & 4 & 5 & 5 & 4 & $4-5$ & 5 \\
\hline III & 4 & 5 & 4 & 4 & 5 & 5 & 4 & $4-5$ & 5 \\
\hline IV & 4 & $4-5$ & 4 & 4 & 5 & 5 & 4 & $4-5$ & 5 \\
\hline $\mathbf{v}$ & 4 & $4-5$ & 4 & $4-5$ & 5 & $4-5$ & 4 & 5 & 4 \\
\hline VI & 5 & 5 & 4 & 5 & 5 & 5 & 5 & 5 & $4-5$ \\
\hline VII & 5 & 5 & 4 & $4-5$ & 5 & 5 & $4-5$ & 5 & 5 \\
\hline VIII & 4 & 4 & 4 & 4 & 4 & 4 & 4 & 4 & 4 \\
\hline IX & 4 & 4 & 4 & 4 & 4 & 4 & 4 & 4 & 4 \\
\hline $\mathbf{x}$ & $4-5$ & 5 & 4 & 4 & 5 & 5 & 4 & $4-5$ & 5 \\
\hline
\end{tabular}

1 The changes are graded with marks 1 - 5 (1: weak, 5: excellent)

${ }^{2}$ AC: Acetate cellulose, CO: Cotton, PA: Polyamide, PES: Polyester, PAN: Polyacrylonitrile, WO:wool 
Table 2. Lightness (L), red-greenness (a) and yellow-blueness (b) values for polyester (D65). ${ }^{(1)}$

\begin{tabular}{cccccccc} 
Compound & $\mathbf{L}^{(2)}$ & $\mathbf{a}^{(2)}$ & $\mathbf{b}^{(2)}$ & Compound & $\mathbf{L}^{(2)}$ & $\mathbf{a}^{(2)}$ & $\mathbf{b}^{(2)}$ \\
\hline $\mathbf{I}$ & 64.01 & 10.59 & 43.34 & $\mathbf{V I}$ & 68.11 & 13.41 & 36.39 \\
$\mathbf{I I}$ & 55.52 & 14.00 & 37.55 & $\mathbf{V I I}$ & 66.73 & 10.27 & 42.43 \\
$\mathbf{I I I}$ & 53.61 & 11.74 & 30.01 & $\mathbf{V I I I}$ & 64.64 & 14.52 & 39.08 \\
$\mathbf{I V}$ & 60.84 & 12.18 & 36.51 & $\mathbf{I X}$ & 63.78 & 12.63 & 33.42 \\
$\mathbf{V}$ & 56.32 & 14.37 & 43.04 & $\mathbf{X}$ & 59.75 & 12.68 & 37.54 \\
\hline
\end{tabular}

1: D65: daylight lamp.

${ }^{2}$ L: Lightness (low or negative value: darkness, high or positive value: lightness); a: Red-greenness (low or negative value: green, high or positive value: red); b: Yellow-blueness (low or negative value: blue, high or positive value: yellow).

Table 3. Color fastness of the compounds on cotton fabric. ${ }^{(1)}$

\begin{tabular}{|c|c|c|c|c|c|c|c|c|c|}
\hline \multirow{3}{*}{ Compound } & \multicolumn{7}{|c|}{ Washing fastness } & \multicolumn{2}{|c|}{$\begin{array}{l}\text { Rubbing } \\
\text { fastness }\end{array}$} \\
\hline & \multirow{2}{*}{$\begin{array}{l}\text { Color } \\
\text { Change }\end{array}$} & \multicolumn{6}{|c|}{ Staining $^{(2)}$} & \multirow{2}{*}{ Dry } & \multirow{2}{*}{ Wet } \\
\hline & & $\mathrm{AC}$ & $\mathrm{CO}$ & $\mathrm{PA}$ & PES & PAN & WO & & \\
\hline $\mathbf{I}$ & 5 & $4-5$ & 4 & 4 & $4-5$ & 5 & 4 & $4-5$ & 4 \\
\hline II & 5 & $4-5$ & 4 & $4-5$ & $4-5$ & $4-5$ & 4 & $4-5$ & 4 \\
\hline III & $4-5$ & 4 & 4 & 4 & 5 & 5 & 4 & $4-5$ & 4 \\
\hline IV & $4-5$ & 4 & 4 & 4 & 4 & $3-4$ & 4 & $4-5$ & 4 \\
\hline $\mathbf{v}$ & 4 & $4-5$ & 4 & 4 & $4-5$ & 5 & 4 & 5 & 4 \\
\hline VI & 4 & $4-5$ & 4 & 4 & $4-5$ & 5 & 4 & 5 & 4 \\
\hline VII & 4 & $4-5$ & 4 & 4 & $4-5$ & 5 & 4 & 5 & 4 \\
\hline VIII & 4 & 4 & 4 & 4 & 4 & 5 & 4 & 5 & 4 \\
\hline IX & 4 & 4 & 4 & 4 & 4 & 4 & 4 & 4 & 4 \\
\hline $\mathbf{X}$ & 4 & 4 & 4 & 4 & 5 & 5 & 4 & 4 & 4 \\
\hline
\end{tabular}

Table 4. Lightness, red-greenness and yellow-blueness values for cotton (D65). ${ }^{(1)}$

\begin{tabular}{cccccccc}
\hline Compound & $\mathbf{L}^{(2)}$ & $\mathbf{a}^{(2)}$ & $\mathbf{b}^{(2)}$ & Compound & $\mathbf{L}^{(2)}$ & $\mathbf{a}^{(2)}$ & $\mathbf{b}^{(2)}$ \\
\hline $\mathbf{I}$ & 85.20 & 2.68 & 11.45 & $\mathbf{V I}$ & 82.66 & 4.39 & 16.96 \\
$\mathbf{I I}$ & 82.24 & 5.03 & 10.04 & $\mathbf{V I I}$ & 82.04 & 4.08 & 18.66 \\
$\mathbf{I I I}$ & 77.16 & 6.47 & 25.64 & $\mathbf{V I I I}$ & 74.28 & 7.86 & 26.53 \\
$\mathbf{I V}$ & 81.53 & 4.96 & 15.73 & $\mathbf{I X}$ & 84.30 & 2.78 & 16.26 \\
$\mathbf{V}$ & 77.96 & 6.16 & 14.65 & $\mathbf{X}$ & 71.22 & 4.95 & 13.47 \\
\hline
\end{tabular}


Table 5. Color fastness of the compounds on wool fabric. ${ }^{(1)}$

\begin{tabular}{|c|c|c|c|c|c|c|c|c|c|}
\hline \multirow{3}{*}{ Compound } & \multicolumn{7}{|c|}{ Washing fastness } & \multicolumn{2}{|c|}{$\begin{array}{l}\text { Rubbing } \\
\text { fastness }\end{array}$} \\
\hline & \multirow{2}{*}{$\begin{array}{l}\text { Color } \\
\text { Change }\end{array}$} & \multicolumn{6}{|c|}{ Staining $^{(2)}$} & \multirow{2}{*}{ Dry } & \multirow{2}{*}{ Wet } \\
\hline & & $\mathrm{AC}$ & $\mathrm{CO}$ & $\mathrm{PA}$ & PES & PAN & WO & & \\
\hline $\mathbf{I}$ & 4 & 4 & 4 & 4 & 4 & 4 & 4 & 5 & 4 \\
\hline II & 4 & 4 & 4 & 4 & 4 & 4 & 4 & 5 & 4 \\
\hline III & 4 & 4 & 4 & 4 & 5 & 5 & 4 & 5 & 4 \\
\hline IV & 4 & 4 & 4 & 4 & 4 & 4 & 4 & 5 & 4 \\
\hline $\mathbf{V}$ & $4-5$ & $4-5$ & 4 & $4-5$ & $4-5$ & 5 & $4-5$ & $4-5$ & 4 \\
\hline VI & $4-5$ & $4-5$ & 4 & 4 & $4-5$ & 5 & 4 & $4-5$ & 4 \\
\hline VII & 4 & $4-5$ & 4 & 4 & $4-5$ & 5 & 4 & $4-5$ & 4 \\
\hline VIII & 4 & 4 & 4 & 4 & 4 & 5 & 4 & 4 & 4 \\
\hline IX & 4 & 4 & 4 & 4 & 4 & 4 & 4 & 4 & 4 \\
\hline $\mathbf{x}$ & 4 & 4 & 4 & 4 & 5 & 5 & 4 & 4 & 4 \\
\hline
\end{tabular}

Table 6. Lightness, red-greenness and yellow-blueness values for wool (D65). ${ }^{(1)}$

\begin{tabular}{cccccccc}
\hline Compound & $\mathbf{L}^{(2)}$ & $\mathbf{a}^{(2)}$ & $\mathbf{b}^{(2)}$ & Compound & $\mathbf{L}^{(2)}$ & $\mathbf{a}^{(2)}$ & $\mathbf{b}^{(2)}$ \\
\hline $\mathbf{I}$ & 54.83 & 12.20 & 41.08 & $\mathbf{V I}$ & 52.70 & 14.71 & 39.60 \\
$\mathbf{I I}$ & 90.46 & 2.02 & -6.25 & $\mathbf{V I I}$ & 49.83 & 15.05 & 40.31 \\
$\mathbf{I I I}$ & 64.86 & 8.37 & 10.52 & $\mathbf{V I I I}$ & 46.34 & 14.41 & 35.83 \\
$\mathbf{I V}$ & 90.94 & 1.73 & -5.10 & $\mathbf{I X}$ & 90.58 & 0.38 & -2.07 \\
$\mathbf{V}$ & 37.48 & 18.01 & 38.86 & $\mathbf{X}$ & 38.16 & 14.93 & 33.15 \\
\hline
\end{tabular}

It is observed that the $\mathbf{L}$ and $\mathbf{b}$ values of $5-\mathrm{Br}$ derivative (I) are higher than those of $5-\mathrm{Cl}$ derivative (II), whereas the a value is lower for cotton fabric (Table 4). On the other hand, the chloro substituent at ortho position (IV: $3-\mathrm{Cl}, 5-\mathrm{Cl}$ ) increases $\mathbf{L}$ value whereas decreases the $\mathbf{a}$ and $\mathbf{b}$ values compared to those of the bromo derivative (III: $3-\mathrm{Br}, 5-\mathrm{Cl}$ ). The $\mathbf{L}$ value of the $5-\mathrm{Br}$ derivative (I) is highest among the compounds having chloro and bromo substituents, namely I, II, III, and IV (similarity to the polyester fabric). In the compounds VI (3-methoxy, ortho position) and VII (4-methoxy, meta position), the $\mathbf{L}$ and $\mathbf{a}$ values are close to each other, whereas the methoxy group at the meta position (VII) increases the b value according to the ortho position. It is seen that the methyl group at the para position (IX) increases the $\mathbf{L}$ value according to the ortho position methyl group (VIII) (84.30 and 74.28 respectively) whereas decreases $\mathbf{a}$ and $\mathbf{b}$ values (Table 4 ).

The $\mathbf{L}, \mathbf{a}$, and $\mathbf{b}$ values for wool fabrics (Table 6) are in a wide range according to the polyester and cotton. These ranges are $90.94-37.48,18.01-$ 0.38 , and $41.08-(-6.25)$ for $\mathbf{L}, \mathbf{a}$, and $\mathbf{b}$, respectively. The highest $\mathbf{L}, \mathbf{a}$, and $\mathbf{b}$ values belong to $\mathbf{I V}, \mathbf{V}$, and $\mathbf{I}$, respectively, whereas the lowest $\mathbf{L}$, $\mathbf{a}$, and $\mathbf{b}$ values are exhibited by the compounds $\mathbf{V}$, $\mathbf{I X}$, and II, respectively. Interestingly, compound $\mathbf{V}$ (4-OH derivative) has the highest $\mathbf{a}$ and lowest $\mathbf{L}$ values.

By comparing I and II for wool fabric (Table 6), it is seen that the $\mathbf{L}$ value of $\mathbf{I I}(5-\mathrm{Cl}$ derivative) is relatively high than that of $\mathbf{I}$ ( $5-\mathrm{Br}$ derivative) ( 90.46 and 54.83 , respectively). The $\mathbf{a}$ and $\mathbf{b}$ values of II $(2.02,-6.25)$ are relatively low, according to those of $\mathbf{I}$ (12.20 and 41.08). There is a similar situation for III $(3-\mathrm{Br}, 5-\mathrm{Cl})$ and IV $(3-\mathrm{Cl}, 5-\mathrm{Cl})$ : The $\mathbf{L}$ value of IV is considerably high ( 64.86 and 90.94 for III and IV, respectively) and the $\mathbf{a}$ and $\mathbf{b}$ values (1.73 and -5.10 for IV, respectively) are considerably low according to those of III (8.37 and 10.52). From these results, it can be claimed that chloro substituent increases $\mathbf{L}$ value whereas decreases the $\mathbf{a}$ and $\mathbf{b}$ values in case of wool. The $\mathbf{L}$, $\mathbf{a}$, and $\mathbf{b}$ values are close to each other for 3methoxy and 4-methoxy derivatives (VI and VII) on wool. The $\mathbf{L}$ values are 90.58 and 46.34 for IX and VIII, respectively: The methyl group at para position (IX) increases the $\mathbf{L}$ value whereas decreases the $\mathbf{a}$ and $\mathbf{b}$ (0.38 and -2.07) values considerably according to the methyl group at ortho position (VIII: 14.41 and 35.83). 
Tables 2, 4, and 6 reveal that the $\mathbf{a}$ and $\mathbf{b}$ values are higher for polyester and wool fabrics according to that of cotton fabric. In addition, it is interesting that the $\mathbf{b}$ values of the compounds III, IV, and IX are negative. It is considered that the $\mathbf{b}$ value of $\mathbf{I X}$ (5-Me derivative) is negative $(-2.07)$ for wool, although that of the VIII (3-Me derivative) is a reasonably positive value such as 35.83 . These two compounds (VIII and IX) show similar behavior toward polyester and cotton while behaving differently on wool in point of the $\mathbf{L}, \mathbf{a}$, and $\mathbf{b}$ values. Contrarily for wool, there is no significant difference in the polyester and cotton fabrics comparing their $\mathbf{L}, \mathbf{a}$, and $\mathbf{b}$ values.

As a conclusion, it is observed that the compounds have $\mathbf{L}, \mathbf{a}$, and $\mathbf{b}$ values at a wide range of wool fabric. It means that the substituent effect is seen more clearly in wool fabrics. Besides, it can be concluded that the position of the substituents is significant on dyeing properties even if slightly, comparing the VI with VII and VIII with IX, the derivatives including the methyl and methoxy groups.

It is possible to say that comparing Tables 2, 4, and 6 , the $\mathbf{L}$ values are inversely proportional to $\mathbf{a}$ and $\mathbf{b}$ values, generally: If the $\mathbf{L}$ values are high, $\mathbf{a}$ and $\mathbf{b}$ values are low.

\section{CONCLUSIONS}

In this study, dry/wet rubbing and washing fastnesses of some Schiff bases derived from 4chloroaminophenol and various benzaldehydes including methyl, chloro, bromo, nitro, methoxy, and hydroxy groups were investigated on polyester, wool and cotton fibers. The compounds exhibit good or excellent rubbing and washing fastness characteristics. Also, the lightness (L), redgreenness (a), and yellow-blueness (b) properties of the compounds were investigated. Dyeing properties of the compounds depend on the substituent positions, and the change in dyeing properties resulted from substituent effect is observed on wool mostly. Interestingly, the $\mathbf{L}, \mathbf{a}$, and $\mathbf{b}$ values of $3-\mathrm{Me}$ and $5-\mathrm{Me}$ derivatives (VIII and IX) are close to each other on polyester and cotton; however, they show significant differences in wool fabric (substituent position effect).

On the other hand, it can be claimed that chlorine substituent increases $\mathbf{L}$ value on wool. Schiff base substituents cause various effects on the fabrics. These result from interactions between the functional groups on the molecule and the fabrics depending on their structure.

\section{ACKNOWLEDGMENTS}

This study was funded by Scientific Research Projects Coordination Unit of Istanbul University Cerrahpaşa.

\section{REFERENCES}

1. Poonia K, Siddiqui S, Arshad M, Kumar D. In vitro anticancer activities of Schiff base and its lanthanum complex. Spectrochim. Acta. A. Mol. Biomol. Spectrosc. 2016;155:146-54.

2. Wang M, Wang LF, Li YZ, Li QZ, Xu ZD, Qu DM. Antitumour activity of transition metal complexes with the thiosemicarbazone derived from 3acetylumbelliferone. Transit Met Chem. 2001;26:307-10.

3. Mokhles MA, Ammar AL, Hanan AM, Samia AM, Mamdouh MA, Ahmed AE. Synthesis, anticancer activity and molecular docking study of Schiff base complexes containing thiazole moiety. Beni-Suef Univ. J. Appl. Sci. 2016;5:85-96.

4. Matar SA, Talib WH, Mustafa MS, Mubarak MS, AIDamen MA. Synthesis, characterization, and antimicrobial activity of Schiff bases derived from benzaldehydes and 3,3'diaminodipropylamine. Arab. J. Chem. 2015;8:850-7.

5. Venugopal KN, Jayashree BS. Microwave-induced synthesis of Schiff bases of bromcoumarins as antibacterials. Indian J. Pharm. Sci. 2008;70:88-91.

6. Pandeya SN, Sriram D, Nath G, DeClercq E. Synthesis, antibacterial, antifungal and anti-HIV evaluation of Schiff and Mannich bases of isatin derivatives with 3-amino-2methylmercapto quinazolin-4(3H)-one. Pharm Acta Helv. 1999;74:11-7.

7. Holla BS, Akberali PM, Shivananda MK. Studies on nitrophenylfuran derivatives: Part XII. Synthesis, characterization, antibacterial and antiviral activities of some nitrophenylfurfurylidene-1,2,4-triazolo[3,4- $b]-1,3,4-$ thiadiazines. Il Farmaco. 2001;56:919-27.

8. Jarrahpour A, Khalili D, De Clercq E, Salmi C, Brunel JM. Synthesis, antibacterial, antifungal and antiviral activity evaluation of some new bis-Schiff bases of isatin and their derivatives. Molecules. 2007;12:1720-30.

9. da Silva CM, da Silva DL, Modolo LV, Alves RB, de Resende MA, Martins CVB, de Fatima A. Schiff bases: A short review of their antimicrobial activities. J Adv Res. $2011 ; 2: 1-8$

10. Singh $H$, Yadav LDS, Mishra SBS. Studies on some antifungal transition metal chelates of $\mathrm{N}$-(5-phenyl-1, 3, 4thiadiazol-2-yl) dithiocarbamic acid. J Inorg Nucl Chem. $1981 ; 43: 1701-4$

11. Joseyphus RS, Nair MS. Antibacterial and Antifungal Studies on Some Schiff Base Complexes of Zinc (II). Mycobiology. 2008;36:93-8.

12. Walsh OM, Meegan MJ, Prendergast RM, Nakib TA. Synthesis of 3-acetoxyazetidin-2-ones and 3hydroxyazetidin-2-ones with antifungal and antibacterial activity. Eur J Med Chem. 1996;31:989-1000. 
13. Harpstrite $S E$, Collins SD, Oksman A, Goldberg DE, Sharma V. Synthesis, characterization, and antimalarial activity of novel schiff-base-phenol and naphthalene-amine ligands. Med. Chem. 2008;4(4):392-5.

14. Aslam MAS, Mahmood SU, Shahid M, Saeed A, Iqbal J. Synthesis, biological assay in vitro and molecular docking studies of new Schiff base derivatives as potential urease inhibitors. Eur. J. Med. Chem. 2011;46:5473-9.

15. Sangeeta S, Ahmad K, Noorussabah N, Bharti $S$, Mishra M.K, Sharma SR, Choudhary M. Synthesis, crystal structures, molecular docking and urease inhibition studies of $\mathrm{Ni}(\mathrm{II})$ and $\mathrm{Cu}(\mathrm{II})$ Schiff base complexes. J. Mol. Struct. 2018;1156:1-11.

16. Anouar EH, Raweh $S$, Bayach I, Taha M, Baharudin MS, Di Meo F, Hasan MH, Adam A, Ismail NH, Weber JF, Trouillas P. Antioxidant properties of phenolic Schiff bases: structure-activity relationship and mechanism of action. Journal of Computer-Aided Mol. Des. 2013;27:951-64

17. Aziz AN, Taha M, Ismail NH, Anouar EH, Yousuf $S$, Jamil W, Awang K, Ahmat KAN, Khan KM, Kashif SM. Synthesis, crystal structure, DFT studies and evaluation of the antioxidant activity of 3,4-dimethoxybenzenamine Schiff bases. Molecules 2014;19:8414-33.

18. Jamshidvand $A$, Sahihi $M$, Mirkhani V, Moghadam $M$, Mohammadpoor-Baltork I, Tangestaninejad S, Rudbari HA, Kargar H, Keshavarzi R, Gharaghani S. Studies on DNA binding properties of new Schiff base ligands using spectroscopic, electrochemical and computationalmethods: Influence of substitutions on DNA-binding. J. Mol. Liq. 2018;253:61-71.

19. Mahmood K, Hashmi W, Ismail H, Mirza B, Twamley B, Akhter Z, Rozas I, Baker RJ. Synthesis, DNA binding and antibacterial activity of metal (II) complexes of a benzimidazole Schiff base. Polyhedron. 2019;157:326-34.

20. Dhanaraj CJ, Nair MS. Synthesis, characterization, and antimicrobial studies of some Schiff-base metal(II) complexes. J Coord Chem. 2009;62:4018-28.

21. Szady-Chelmieniecka A, Grech E, Rozwadowski Z, Dziembowska T, Schilf W, Kamienski B. Multinuclear NMR study of the intramolecular hydrogen bond in SchiffMannich bases. J Mol Struct. 2001;565:125-8.

22. Jones RD, Summerville DA, Basolo F. Synthetic oxygen carriers related to biological systems. Chem Rev. 1979;17:139-79.
23. Hadjoudis E, Mavridis IM. Photochromism and thermochromism of Schiff bases in the solid state structural aspects. Chem Soc Rev. 2004;33:579-88.

24. Bhat K, Chang KJ, Aggarwal MD, Wang WS, Penn BG, Frazier DO. Synthesis and characterization of various Schiff bases for non-linear optical applications. Mater Chem Phys. 1996;44:261-6.

25. Mahmoud MR, El-Gyar SA, Moustafa AA, Shaker A. $\mathrm{Ni}$ (II) complexes of some polyfunctional $\mathrm{n}$ Naphthylideneamino acids. Polyhedron. 1987;6:1017-20.

26. Qing-Yu H, Zheng-Hua M, Ya-Me Z. Preparation and oxygenation of manganese(II) complexes of imines derived from salicylaldehyde and amino acids. J Coord Chem. 1990;21:199-207.

27. Memon SQ, Memon N, Mallah A, Soomro R, Khuhawar MY. Schiff Bases as Chelating Reagents for Metal Ions Analysis. Current Analytical Chem. 2014;10:393-417.

28. Prajila $M$, Joseph A. Inhibition of mild steel corrosion in hydrochloric using three different 1,2,4-triazole Schiff's bases: A comparative study of electrochemical, theoretical and spectroscopic results. J Mol Liq. 2017; 241:1-8.

29. Gupta NK, Quraishi MA, Verma C, Mukherjee AK. Green Schiff's bases as corrosion inhibitors for mild steel in $1 \mathrm{M} \mathrm{HCl}$ solution: experimental and theoretical approach. RSC Advances. 2016; 104:102076-87.

30. Samadhiya S, Halve A. Synthetic utility of Schiff bases as potential herbicidal agents. Orient J. Chem. 2001;17 (electronic).

31. Papic S, Koprivanac N, Grabaric Z, Parac-Osterman D. Metal complex dyes of nickel with Schiff bases. Dyes and Pigments. 1994;25:229-40.

32. Ahmed DS, El-Hiti GA, Hameed AS, Yousif E, Ahmed A. New tetra-Schiff bases as efficient photostabilizers for poly(vinyl chloride). Molecules. 2017;22:1506-21.

33. Cinarli A, Gürbüz D, Tavman A, Birteksöz AS. Spectral characterization and antimicrobial activity of some Schiff bases derived from 4-chloro-2-aminophenol and various salicylaldehyde derivatives. Chinese J Chem. 2012;30:449-59.

34. Cinarli A, Gürbüz D, Tavman A, Birteksöz AS. Synthesis, spectral characterizations and antimicrobial activity of some Schiff bases of 4-chloro-2-aminophenol. Bull Chem Soc Ethiop. 2011;25:407-17. 